University of Nebraska - Lincoln

DigitalCommons@University of Nebraska - Lincoln

\title{
Grazing Management, Season, and Drought Contributions to Near- Surface Soil Property Dynamics in Semiarid Rangeland
}

\author{
M. A. Liebig \\ United States Department of Agriculture- Agricultural Research Service, mark.liebig@ars.usda.gov
}

S. L. Kronberg

United States Department of Agriculture- Agricultural Research Service, scott.kronberg@ars.usda.gov

J. R. Hendrickson

United States Department of Agriculture- Agricultural Research Service, john.hendrickson@ars.usda.gov

J. R. Gross

United States Department of Agriculture- Agricultural Research Service

Follow this and additional works at: https://digitalcommons.unl.edu/usdaarsfacpub

Liebig, M. A.; Kronberg, S. L.; Hendrickson, J. R.; and Gross, J. R., "Grazing Management, Season, and Drought Contributions to Near-Surface Soil Property Dynamics in Semiarid Rangeland" (2014).

Publications from USDA-ARS / UNL Faculty. 1456.

https://digitalcommons.unl.edu/usdaarsfacpub/1456

This Article is brought to you for free and open access by the U.S. Department of Agriculture: Agricultural Research Service, Lincoln, Nebraska at DigitalCommons@University of Nebraska - Lincoln. It has been accepted for inclusion in Publications from USDA-ARS / UNL Faculty by an authorized administrator of DigitalCommons@University of Nebraska - Lincoln. 


\title{
Grazing Management, Season, and Drought Contributions to Near-Surface Soil Property Dynamics in Semiarid Rangeland
}

\author{
M. A. Liebig, ${ }^{1}$ S. L. Kronberg, ${ }^{2}$ J. R. Hendrickson, ${ }^{3}$ and J. R. Gross ${ }^{4}$ \\ Authors are ${ }^{1}$ Research Soil Scientist, ${ }^{2}$ Research Animal Scientist, and ${ }^{3}$ Research Rangeland Management Specialist, US Department of Agriculture- \\ Agricultural Research Service, Mandan, ND 58554, USA; and ${ }^{4}$ Physical Scientist, US Department of Agriculture Forest Service, Rifle, CO 81650, USA.
}

\begin{abstract}
Grazing management effects on soil property dynamics are poorly understood. A study was conducted to assess effects of grazing management and season on soil property dynamics and greenhouse gas flux within semiarid rangeland. Grazing management treatments evaluated in the study included two permanent pastures differing in stocking rate (moderately and heavily grazed pastures) and a fertilized, heavily grazed crested wheatgrass (Agropyron desertorum [Fisch. ex. Link] Schult.) pasture near Mandan, North Dakota. Over a period of $3 \mathrm{yr}$, soil properties were measured in the spring, summer, and fall at 0-5 $\mathrm{cm}$ and 5-10 cm. Concurrent to soil-based measurements, fluxes of carbon dioxide, methane, and nitrous oxide were measured on 1-wk to 2-wk intervals and related to soil properties via stepwise regression. High stocking rate and fertilizer nitrogen (N) application within the crested wheatgrass pasture contributed to increased soil bulk density and extractable $\mathrm{N}$, and decreased soil $\mathrm{pH}$ and microbial biomass compared to permanent pastures. Soil nitrate nitrogen tended to be greatest at peak aboveground biomass, whereas soil ammonium nitrogen was greatest in early spring. Drought conditions during the third year of the study contributed to nearly two-fold increases in extractable $\mathrm{N}$ under the crested wheatgrass pasture and the heavily grazed permanent pasture, but not the moderately grazed permanent pasture. Stepwise regression found select soil properties to be modestly related to soil-atmosphere greenhouse gas fluxes, with model $r^{2}$ ranging from 0.09 to 0.76 . Electrical conductivity was included most frequently in stepwise regressions and, accordingly, may serve as a useful screening indicator for greenhouse gas "hot spots" in grazing land.
\end{abstract}

Key Words: electrical conductivity, greenhouse gas emissions, Northern Plains, soil acidification

\section{INTRODUCTION}

Rangeland soils perform critical functions affecting both forage production and environmental regulation (Follett and Reed 2010; Teague et al. 2011). Rangeland soils are also looked upon to serve as a foundation for ecosystem resilience under increasingly dynamic weather and market conditions (Westoby et al. 1989; Dougill et al. 1998). Accordingly, strategic-minded land managers recognize the importance of soil as a cornerstone of sustained profitability and long-term ecosystem health (Darnhofer et al. 2010), and thereby value information related to its management under changing circumstances.

Limited plant and litter cover over the soil coupled with highly sensitive plant communities make near-surface soil conditions in semiarid rangelands particularly susceptible to change. Management-related influences often serve to exacerbate soil property dynamics in semiarid rangelands (Steffens et al. 2008), with concomitant effects on critical ecosystem

This publication is based on work supported by the USDA Agricultural Research Service GRACEnet Project and Long Term Agro-Ecosystem Research Network.

The US Dept of Agriculture, Agricultural Research Service (USDA-ARS) is an equal opportunity/ affirmative action employer and all agency services are available without discrimination. Mention of commercial products and organizations in this manuscript is solely to provide specific information. It does not constitute endorsement by USDA-ARS over other products and organizations not mentioned.

Correspondence: Mark A. Liebig, USDA-ARS, Northern Great Plains Research Laboratory, P0 Box 459, Mandan, ND 58554, USA. Email: mark.liebig@ars.usda.gov

Manuscript received 27 September 2013; manuscript accepted 6 March 2014.

(c) 2014 The Society for Range Management services (Daly et al. 1997). Grazing, the predominant use of semiarid rangelands, can variably impact soil properties depending on the frequency, intensity, and duration of livestock influence. Long-term overgrazing has been shown to deteriorate soil physical and chemical properties in semiarid rangelands, contributing to decreased water retention, increased erosion, and enhanced soil nutrient depletion (Chen et al. 2011; Teague et al. 2011). Conversely, good grazing management practices in semiarid rangelands can create soil conditions with improved nutrient cycling and hydrological attributes (Thurow 1991; Banerjee et al. 2000; Ingram et al. 2008).

Understanding of grazing management impacts on soil properties can be captured through single "snapshot" evaluations, assuming treatment features have had adequate time to influence soil condition. Conclusions from such evaluations, however, must be tempered by the inherent limitation of single point-in-time measurements, which-depending on the soil property-may not adequately characterize treatment effects over a growing season or between years, where weatherinduced influences on soil condition can be significant (Chen et al. 2001; Whalen et al. 2003). Studies evaluating management influences on soil properties within growing seasons and across consecutive years in semiarid rangelands are needed to provide insight into ecosystem resilience, particularly if the study period encompasses extreme weather conditions.

Given this context, we sought to evaluate near-surface soil property dynamics in three long-term grazing management systems in central North Dakota. Evaluations were conducted three times during the growing season over three consecutive years. To leverage information emanating from the concurrent 
assessment of soil-atmosphere greenhouse gas fluxes for the same treatments (Liebig et al. 2010a, 2013), potential associations between soil properties and carbon dioxide $\left(\mathrm{CO}_{2}\right)$, methane $\left(\mathrm{CH}_{4}\right)$, and nitrous oxide $\left(\mathrm{N}_{2} \mathrm{O}\right)$ fluxes were investigated. We hypothesized 1) intra- and interannual variation in soil properties would increase with nitrogen $(\mathrm{N})$ application and/or increasing stocking rate, and 2) soilatmosphere greenhouse gas fluxes would be most frequently associated with plant-available soil $\mathrm{N}$.

\section{METHODS}

\section{Site and Treatment Description}

The research site was located at the US Dept of Agriculture, Agricultural Research Service Northern Great Plains Research Laboratory near Mandan, North Dakota (lat 46 $46^{\prime} 12^{\prime \prime} \mathrm{N}$, long $\left.100^{\circ} 55^{\prime} 59^{\prime \prime} \mathrm{W}\right)$. The site is characterized by a semiarid, continental climate, with long-term (90-yr) mean annual precipitation and temperature of $410 \mathrm{~mm}$ and $4^{\circ} \mathrm{C}$, respectively. The site is situated on a gently rolling landscape (0-3\% slope). The soil possesses a silty loess mantle overlying Wisconsin age till, and is categorized as a blend of Temvik and Wilton silt loams (Fine-silty, mixed, superactive, frigid Typic and Pachic Haplustolls; USDA 2013). General soil characteristics in the surface $30 \mathrm{~cm}$ include $280 \mathrm{~g} \cdot \mathrm{kg}^{-1}$ sand, $190 \mathrm{~g} \cdot \mathrm{kg}^{-1}$ clay, $27.3 \mathrm{~g}$ carbon $(\mathrm{C}) \cdot \mathrm{kg}^{-1}$ soil organic $\mathrm{C}$, and $18.0 \mathrm{cmol} \cdot \mathrm{kg}^{-1}$ cation exchange capacity.

Treatments evaluated in the study included two permanent vegetation pastures and one seeded forage pasture, each of which belong to a network of long-term grazing studies investigating grazing management effects on animal performance and plant species composition and production (Reeves et al. 2013). The permanent pastures included a moderately grazed pasture (MGP) and heavily grazed pasture (HGP), both established in 1916 on native rangeland and managed without the application of tillage, fertilizer, herbicides, or fire (Frank et al. 2006). Based on species composition measurements in 2004, Kentucky bluegrass (Poa pratensis L.) was the dominant species in MGP, comprising $64 \%$ of the relative species composition. Other plant species in MGP included sedges (Carex filifolia Nutt. and Carex heliophila Mack.), green needlegrass (Nassella viridula [Trin.] Barkworth) and blue grama (Bouteloua gracilis [H.B.K.] Lag. ex Griffiths), with lesser amounts of purple threeawn (Aristida purpurea Nutt), needle-and-thread (Hesperostipa comata [Trin. \& Rupr.] Barkworth), and western wheatgrass (Pascopyrum smithii [Rybd] Löve). The HGP was dominated by blue grama (40\% of the species composition) and Kentucky bluegrass (30\% of the species composition) while the remainder of the species were similar to MGP.

The seeded forage was a crested wheatgrass (Agropyron desertorum [Fisch. ex. Link] Schult.) pasture (CWP), established in 1932 by planting into previously tilled native range. The predominant plant species in CWP was crested wheatgrass $(50 \%)$, with blue grama, sedges, and various cool-season native grasses comprising the remainder of the species. Following practices initiated in 1963 to increase forage production, CWP was fertilized in the fall of each year with ammonium nitrate at $45 \mathrm{~kg} \mathrm{~N} \cdot \mathrm{ha}^{-1}$.
Yearling steers were used to graze all pastures from mid-May to early October each year. Stocking rates for MGP and HGP were $2.6 \mathrm{ha} \cdot$ steer $^{-1}$ and $0.9 \mathrm{ha} \cdot$ steer $^{-1}$ (0.39 animals $\cdot \mathrm{ha}^{-1}$ and 1.1 animals $\left.\cdot \mathrm{ha}^{-1}\right)$, respectively, while stocking rates within CWP were $0.4 \mathrm{ha} \cdot$ steer $^{-1}$ (2.3 animals $\left.\cdot \mathrm{ha}^{-1}\right)$ in late spring/ early summer and $0.9 \mathrm{ha} \cdot$ steer $^{-1}\left(1.2\right.$ animals $\left.\cdot \mathrm{ha}^{-1}\right)$ for the remainder of the grazing season. Only in instances of extreme drought was grazing curtailed based on forage availability.

The MGP, HGP, and CWP occupied 15.4 ha, 2.8 ha, and 2.6 ha, respectively, and were situated within $1 \mathrm{~km}$ of each other. None of the grazing treatments were replicated, which was common for field experiments prior to the use of statistics (Sarvis 1923).

\section{Soil and Gas Sample Collection and Analyses}

Soil bulk density, extractable nitrate nitrogen $\left(\mathrm{NO}_{3}-\mathrm{N}\right)$ and ammonium nitrogen $\left(\mathrm{NH}_{4}-\mathrm{N}\right)$, electrical conductivity, soil $\mathrm{pH}$, and microbial biomass $\mathrm{C}$ were evaluated in the grazing treatments in 2004, 2005, and 2006. Soil properties were selected for analysis based on their expected contribution to provide insight into changes in soil function, as well as recommendations for required and optional analyses for Agricultural Research Service GRACEnet projects (Liebig et al. 2010b). Soil samples were collected three times per year (mid-April, late July, early October) in four randomly selected locations near the center of each treatment with a $3.5-\mathrm{cm}$ (inner diameter) step-down probe at depths of $0-5 \mathrm{~cm}$ and $5-10 \mathrm{~cm}$. At each location, eight soil cores were collected and composited by depth. Immediately following collection, samples were dried at $35^{\circ} \mathrm{C}$ for $3-4 \mathrm{~d}$ and ground by hand to pass a $2.0-\mathrm{mm}$ sieve. Identifiable plant material $(>2.0 \mathrm{~mm})$ was removed during sieving. Soil $\mathrm{NO}_{3}-\mathrm{N}$ and $\mathrm{NH}_{4}-\mathrm{N}$ were estimated from $1: 10$ soil: potassium chloride $(2 \mathrm{M})$ extracts using cadmium reduction followed by a modified Griess-Ilosvay method and indophenol blue reaction (Mulvaney 1996). Electrical conductivity and $\mathrm{pH}$ were estimated from a 1:1 soil: water mixture (Watson and Brown 1998; Whitney 1998). Soil microbial biomass $\mathrm{C}$ was estimated using the microwave irradiation technique method, but only for the late July sampling (Islam and Weil 1998). Due to the need for moist samples, an extra set of six cores per location were collected as outlined above and processed by sieving through a $2.0-\mathrm{mm}$ sieve at field moisture content. Fifty grams of soil was incubated $10 \mathrm{~d}$ at $55 \%$ waterfilled pore space in the presence of $10 \mathrm{~mL}$ of $2.0 \mathrm{M}$ sodium hydroxide. Carbon dioxide content was determined by single end-point titration with $0.1 \mathrm{M}$ hydrochloric acid (Paul et al. 1996), and the flush of $\mathrm{CO}_{2}-\mathrm{C}$ following irradiation was calculated without subtraction of a $10-\mathrm{d}$ control as suggested by Franzluebbers et al. (1999). Gravimetric data were converted to a volumetric basis for each sampling depth using field-measured soil bulk density (Blake and Hartge 1986). All data were expressed on an oven-dry basis.

Measurement protocols for assessment of $\mathrm{CO}_{2}, \mathrm{CH}_{4}$, and $\mathrm{N}_{2} \mathrm{O}$ fluxes have been thoroughly described elsewhere (Liebig et al. 2010b, 2013). Briefly, gas fluxes were measured in the grazing treatments from 21 October 2003 to 24 October 2006 using static chamber methodology (Hutchinson and Mosier 1981). Gas samples were collected in each treatment from twopart chambers consisting of six anchors with a plastic cap (19.6 
Table 1. Mean \pm SEM soil property values across years and seasons at $0-5 \mathrm{~cm}$ and $5-10 \mathrm{~cm}$ for grazing treatments evaluated in study. $P$ values for comparisons within an effect are provided below listed means.

\begin{tabular}{|c|c|c|c|c|c|c|}
\hline Depth/treatment & $\begin{array}{l}\text { Soil bulk density } \\
\quad\left(\mathrm{Mg} \cdot \mathrm{m}^{-3}\right)\end{array}$ & $\begin{array}{l}\text { Electrical conductivity } \\
\left(\mathrm{dS} \cdot \mathrm{m}^{-1}\right)\end{array}$ & $\begin{array}{c}\text { Soil pH } \\
\left(-\log \left[\mathrm{H}^{+}\right]\right)\end{array}$ & $\begin{array}{c}\text { Soil } \mathrm{NO}_{3}-\mathrm{N} \\
\left(\mathrm{kg} \mathrm{N} \cdot \mathrm{ha}^{-1}\right)^{1}\end{array}$ & $\begin{array}{l}\text { Soil } \mathrm{NH}_{4}-\mathrm{N} \\
\left(\mathrm{kg} \mathrm{N} \cdot \mathrm{ha}^{-1}\right)\end{array}$ & $\begin{array}{c}\text { Microbial biomass C } \\
\left(\mathrm{kg} \mathrm{C} \cdot \mathrm{ha}^{-1}\right)\end{array}$ \\
\hline \multicolumn{7}{|l|}{$0-5 \mathrm{~cm}$} \\
\hline Crested wheatgrass & $0.82 \pm 0.01$ SEM & $0.26 \pm 0.02$ SEM & $4.83 \pm 0.03$ SEM & $10.1 \pm 1.1$ SEM & $9.2 \pm 0.5$ SEM & $169 \pm 20$ SEM \\
\hline Heavily grazed & $0.76 \pm 0.01$ SEM & $0.29 \pm 0.01$ SEM & $6.59 \pm 0.02$ SEM & $2.6 \pm 0.5$ SEM & $2.6 \pm 0.2$ SEM & $640 \pm 58$ SEM \\
\hline Moderately grazed & $0.72 \pm 0.01$ SEM & $0.28 \pm 0.01$ SEM & $6.17 \pm 0.02$ SEM & $2.6 \pm 0.4$ SEM & $3.2 \pm 0.5$ SEM & $534 \pm 42$ SEM \\
\hline$P$ value & $<0.0001$ & 0.2638 & $<0.0001$ & $<0.0001$ & $<0.0001$ & $<0.0001$ \\
\hline \multicolumn{7}{|l|}{$5-10 \mathrm{~cm}$} \\
\hline Crested wheatgrass & $1.15 \pm 0.01$ SEM & $0.28 \pm 0.01$ SEM & $5.79 \pm 0.04$ SEM & $5.4 \pm 0.7$ SEM & $2.9 \pm 0.4$ SEM & $422 \pm 46$ SEM \\
\hline Heavily grazed & $1.01 \pm 0.01$ SEM & $0.25 \pm 0.01$ SEM & $6.51 \pm 0.02$ SEM & $1.1 \pm 0.2$ SEM & $1.7 \pm 0.2$ SEM & $425 \pm 42$ SEM \\
\hline Moderately grazed & $1.06 \pm 0.01$ SEM & $0.24 \pm 0.01$ SEM & $6.32 \pm 0.03$ SEM & $1.5 \pm 0.2$ SEM & $1.9 \pm 0.2$ SEM & $345 \pm 39$ SEM \\
\hline$P$ value & $<0.0001$ & 0.0458 & $<0.0001$ & $<0.0001$ & 0.0082 & 0.2734 \\
\hline
\end{tabular}

${ }^{1} \mathrm{NO}_{3}-\mathrm{N}$ indicates nitrate nitrogen; $\mathrm{NH}_{4}-\mathrm{N}$, ammonium nitrogen; and $\mathrm{C}$, carbon.

$\mathrm{cm}$ inner diameter; $10.0 \mathrm{~cm}$ height), vent tube, and sampling port. Samples were collected with a $20-\mathrm{mL}$ syringe at installation $(0 \mathrm{~min})$, and at $15 \mathrm{~min}$ and $30 \mathrm{~min}$ after installation at approximately 1000 hours each sampling day. Following collection, gas samples were injected into $12-\mathrm{mL}$ evacuated Exetainer glass vials sealed with butyl rubber septa (Labco Limited, Buckinghamshire, United Kingdom) and analyzed for $\mathrm{CO}_{2}, \mathrm{CH}_{4}$, and $\mathrm{N}_{2} \mathrm{O}$ concentrations using a Shimadzu GC-17A gas chromatograph (Shimadzu Scientific Instruments, Kyoto, Japan). Gas flux was calculated from the change in concentration in the chamber headspace over time (Hutchinson and Mosier 1981). Gas flux measurements were made one to two times per week when near-surface soil depths were unfrozen or during midwinter thawing periods. Otherwise, gas fluxes were measured every other week.

Precipitation was monitored daily at a North Dakota Agricultural Weather Network (NDAWN) station within 1 $\mathrm{km}$ of the grazing treatments. Applicable data were downloaded after each gas sampling event from the NDAWN website (NDAWN 2014).

\section{Data Analyses}

Because of a lack of replication, anchors and sampling locations served as pseudoreplicates in each treatment for gas flux and soil properties measurements, respectively (Gomez and Gomez 1984). Accordingly, results from statistical analyses should be interpreted with caution. Although this approach is not ideal, it seems a reasonable compromise given the long-term value of the grazing treatments. At the time of this study, the CWP and permanent pastures were $71 \mathrm{yr}$ old and $87 \mathrm{yr}$ old, respectively, making them rare among grazing studies in North America.

A mixed repeated measures model was used to analyze the effects of grazing treatment, season, and year on soil properties and gas flux (Littell et al. 1996). The analysis used a time series covariance structure in the repeated measures model, where correlations decline over time (Phillips et al. 2009). For purposes of partitioning gas flux measurements by season, the following dates were used: 1 March-31 May=spring, 1 June31 August $=$ summer, 1 September -30 November $=$ fall, and 1 December-28/29 February=winter. For soil properties, samples collected in mid-April, late July, early October corre- sponded to spring, summer, and fall seasons, respectively. Tested effects used a significance criterion of $P \leq 0.05$ to discriminate between means. Stepwise regression was used to evaluate the contribution of soil properties to $\mathrm{CO}_{2}, \mathrm{CH}_{4}$, and $\mathrm{N}_{2} \mathrm{O}$ flux (SAS Institute 1990). Partial $r^{2}$ values in each regression were selected using a significance criterion of $P \leq 0.1$. Soil depths were analyzed separately in the repeated measures model and stepwise regression. Where applicable, associations between measured variables were identified using Pearson correlation analysis.

\section{RESULTS}

\section{Precipitation During Study}

Precipitation received over the course of the study was below normal, with 2 of 3 yr categorized as moderate to severe drought for most of the growing season (National Drought Mitigation Center 2014). Precipitation at the site was $132 \mathrm{~mm}$ in 2003-2004, $450 \mathrm{~mm}$ in 2004-2005, and $216 \mathrm{~mm}$ in 2005-2006 (beginning and ending in mid-October each year; data not shown). Most precipitation events $(96 \%)$ were small $\left(<5 \mathrm{~mm} \cdot\right.$ event $\left.^{-1}\right)$, and snow was minimal, with continuous snow cover limited to December 2003 to March 2004 (Liebig et al. 2010a).

\section{Effects of Grazing Treatment}

Grazing management significantly affected soil properties evaluated in the study (Table 1). The CWP possessed greater soil bulk density than MGP at $0-5 \mathrm{~cm}$, whereas at $5-10 \mathrm{~cm}$ soil bulk density was greater in CWP compared to both permanent pastures. Soil $\mathrm{pH}$ fell within strongly acid to very strongly acid categories for CWP (4.5 to 5.5), slightly acid category for MGP (6.1 to 6.5), slightly acid to neutral categories for HGP (6.1 to 7.3; USDA 1993), and differed significantly between treatments for both depths. Moreover, soil $\mathrm{pH}$ differences among treatments were most pronounced at $0-5 \mathrm{~cm}$, where $\mathrm{pH}$ in CWP was 1.34 and 1.76 units lower than in HGP and MGP, respectively. Soil $\mathrm{NO}_{3}-\mathrm{N}$ and $\mathrm{NH}_{4}-\mathrm{N}$ was generally low across treatments $\left(<11 \mathrm{~kg} \mathrm{~N} \cdot \mathrm{ha}^{-1} \cdot \mathrm{depth}^{-1}\right)$, but ranged from 1.6 times to 4.2 times greater in CWP than permanent pastures. Microbial biomass $\mathrm{C}$ at $0-5 \mathrm{~cm}$ was over three times greater in permanent 


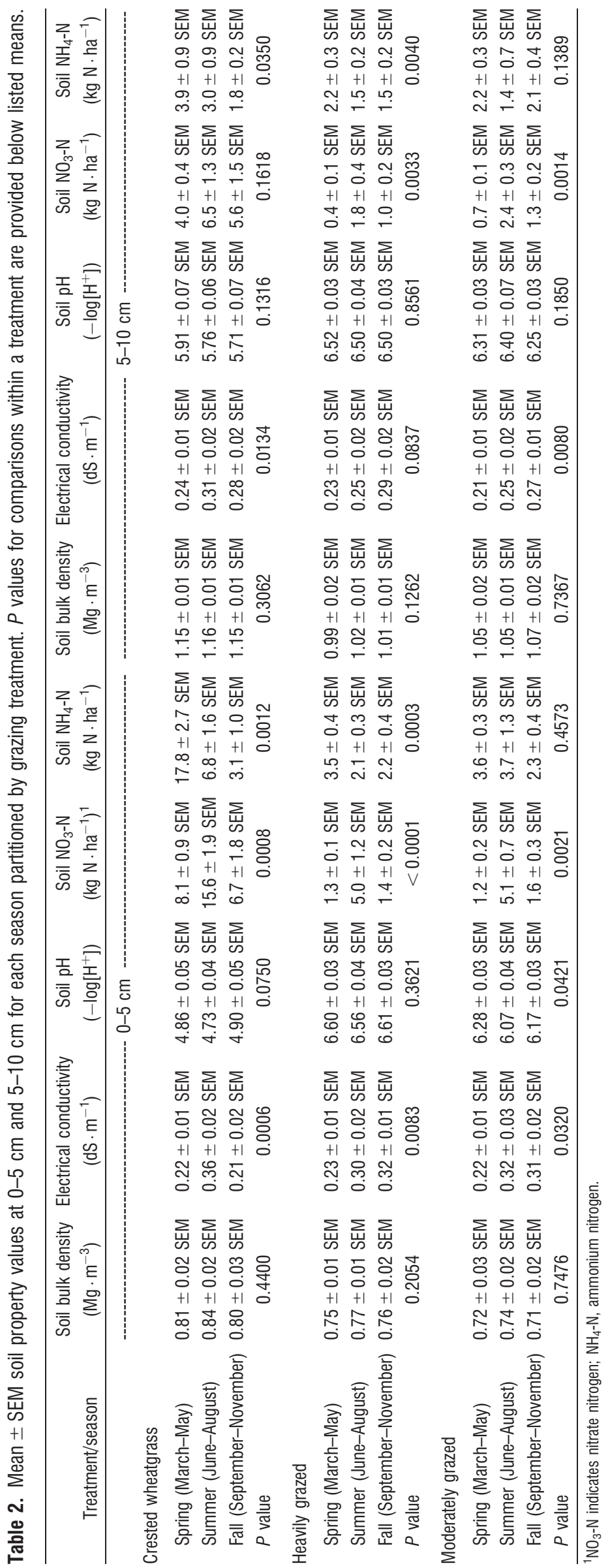


Table 3. Mean \pm SEM soil property values at $0-5$ and $5-10 \mathrm{~cm}$ for each year partitioned by grazing treatment. $P$ values for comparisons within a treatment are provided below listed means.

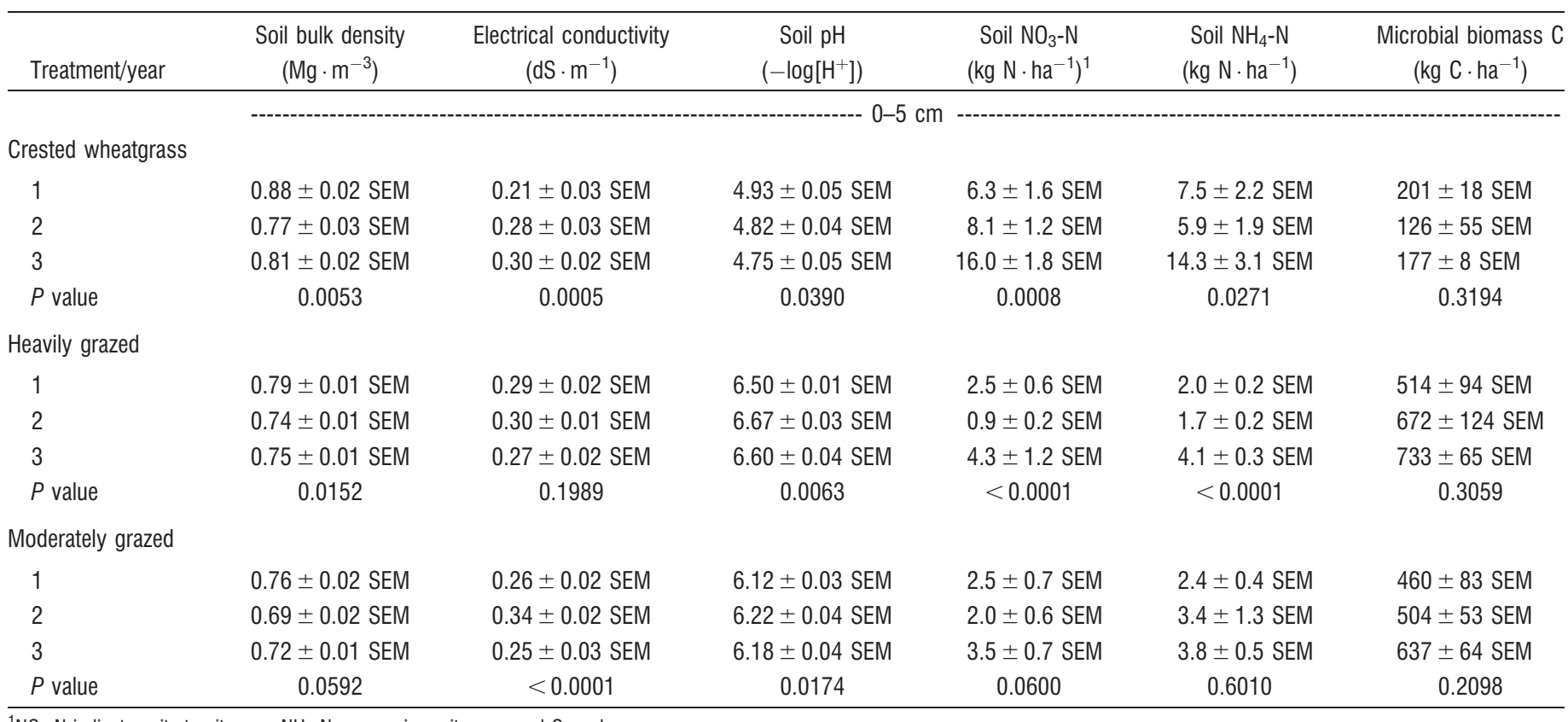

${ }^{1} \mathrm{NO}_{3}-\mathrm{N}$ indicates nitrate nitrogen; $\mathrm{NH}_{4}-\mathrm{N}$, ammonium nitrogen; and $\mathrm{C}$, carbon.

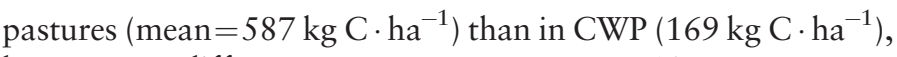
but was not different among treatments at $5-10 \mathrm{~cm}$.

\section{Effects of Season and Year}

Significant differences in soil properties across seasons were largely limited to electrical conductivity and extractable N. Soil bulk density did not differ across seasons at either depth, with values fluctuating no more than $0.04 \mathrm{Mg} \cdot \mathrm{m}^{-3}$ between seasons (Table 2). Soil pH was nearly as nonresponsive to season, with significant $\mathrm{pH}$ change only observed in $\mathrm{MGP}$ at $0-5 \mathrm{~cm}$ (spring $>$ summer; $P=0.0421$ ). Changes in electrical conductivity across seasons were observed in five of six treatment $\times$ depth combinations, with values generally lowest in spring and $0.02 \mathrm{dS} \cdot \mathrm{m}^{-1}$ to $0.14 \mathrm{dS} \cdot \mathrm{m}^{-1}$ higher in summer. Summer electrical conductivity values were generally maintained through fall, with the notable exception of CWP at 0-5 $\mathrm{cm}$, in which electrical conductivity returned to its springtime status. Both soil $\mathrm{NO}_{3}-\mathrm{N}$ and $\mathrm{NH}_{4}-\mathrm{N}$ were highly responsive to season, though fluctuations in both forms of $\mathrm{N}$ differed considerably by depth and treatment. Soil $\mathrm{NO}_{3}-\mathrm{N}$ was generally greatest in summer and least in spring, with seasonal fluctuations greater at $0-5 \mathrm{~cm}\left(3.7 \mathrm{~kg} \mathrm{~N} \cdot \mathrm{ha}^{-1}\right.$ to $8.9 \mathrm{~kg}$ $\left.\mathrm{N} \cdot \mathrm{ha}^{-1}\right)$ than at $5-10 \mathrm{~cm}\left(1.4 \mathrm{~kg} \mathrm{~N} \cdot \mathrm{ha}^{-1}\right.$ to $\left.1.7 \mathrm{~kg} \mathrm{~N} \cdot \mathrm{ha}^{-1}\right)$. Among grazing treatments, soil $\mathrm{NO}_{3}-\mathrm{N}$ at $0-5 \mathrm{~cm}$ varied most across seasons in CWP (8.9 $\left.\mathrm{kg} \mathrm{N} \cdot \mathrm{ha}^{-1}\right)$ compared to the permanent pastures $\left(\right.$ mean $\left.=3.8 \mathrm{~kg} \mathrm{~kg} \mathrm{~N} \cdot \mathrm{ha}^{-1}\right)$, though seasonal differences across treatments at $5-10 \mathrm{~cm}$ were not nearly as pronounced $\left(1.4 \mathrm{~kg} \mathrm{~N} \cdot \mathrm{ha}^{-1}\right.$ to $\left.1.7 \mathrm{~kg} \mathrm{~N} \cdot \mathrm{ha}^{-1}\right)$. Soil $\mathrm{NH}_{4}-\mathrm{N}$ was generally greatest in spring and decreased through summer and fall. For both depths, seasonal fluctuations in soil $\mathrm{NH}_{4}-\mathrm{N}$ was greatest in CWP $\left(14.7 \mathrm{~kg} \mathrm{~N} \cdot \mathrm{ha}^{-1}\right.$ and $2.1 \mathrm{~kg}$ $\mathrm{N} \cdot \mathrm{ha}^{-1}$ for $0-5 \mathrm{~cm}$ and $5-10 \mathrm{~cm}$, respectively) and lowest in permanent pastures $\left(1.4 \mathrm{~kg} \mathrm{~N} \cdot \mathrm{ha}^{-1}\right.$ and $0.7 \mathrm{~kg} \mathrm{~N} \cdot \mathrm{ha}^{-1}$ to 0.8 $\mathrm{kg} \mathrm{N} \cdot \mathrm{ha}^{-1}$ for $0-5 \mathrm{~cm}$ and $5-10 \mathrm{~cm}$, respectively).
With the exception of microbial biomass C, measured soil properties were affected by year, particularly in the surface 0-5 $\mathrm{cm}$ depth (Table 3). Soil bulk density was significantly greater in year 1 than years 2 and 3 in CWP and HGP at 0-5 cm. Annual change in electrical conductivity was variable among treatments at $0-5 \mathrm{~cm}$, with greater electrical conductivity in years 2 and 3 than year 1 in CWP, no significant year effect in HGP, and greater electrical conductivity in year 2 than years 1 and 3 in MGP. At $5-10 \mathrm{~cm}$, annual fluctuation in electrical conductivity differed only in MGP (years 1 and $2>$ year 3; $P=0.0004)$. Soil $\mathrm{pH}$ at $0-5 \mathrm{~cm}$ decreased from year 1 to year 3 in CWP, whereas in permanent pastures soil $\mathrm{pH}$ was greater in years 2 and 3 compared to year 1 . At $5-10 \mathrm{~cm}$, soil $\mathrm{pH}$ in MGP followed the same significant trend observed at 0-5 cm.

Soil $\mathrm{NO}_{3}-\mathrm{N}$ and $\mathrm{NH}_{4}-\mathrm{N}$ followed similar patterns across years at $0-5 \mathrm{~cm}$, with values approximately two-fold greater in year 3 compared to years 1 and 2 in CWP and HGP (Table 3). Annual fluctuations in soil $\mathrm{NO}_{3}-\mathrm{N}\left(1.5 \mathrm{~kg} \mathrm{~N} \cdot \mathrm{ha}^{-1}\right)$ and $\mathrm{NH}_{4}$ $\mathrm{N}\left(1.4 \mathrm{~kg} \mathrm{~N} \cdot \mathrm{ha}^{-1}\right)$ in MGP at $0-5 \mathrm{~cm}$ were not significantly different. At 5-10 cm, soil $\mathrm{NH}_{4}-\mathrm{N}$ in CWP followed a similar trend in the surface depth with approximately three-fold greater values in year 3 than years 1 and 2 . Though annual fluctuations were small $\left(1.1 \mathrm{~kg} \mathrm{~N} \cdot \mathrm{ha}^{-1}\right.$ to $\left.1.8 \mathrm{~kg} \mathrm{~N} \cdot \mathrm{ha}^{-1}\right)$, HGP possessed significantly lower soil $\mathrm{NO}_{3}-\mathrm{N}$ and $\mathrm{NH}_{4}-\mathrm{N}$ in year 2 compared to years 1 and 3. Annual $\mathrm{N}$ dynamics in MGP were only significantly different for soil $\mathrm{NO}_{3}-\mathrm{N}$ at $5-10 \mathrm{~cm}$, where the value in year 1 was greater than in year $2(1.9 \mathrm{~kg}$ $\mathrm{N} \cdot \mathrm{ha}^{-1}$ vs. $1.1 \mathrm{~kg} \mathrm{~N} \cdot \mathrm{ha}^{-1} ; P=0.0251$ ).

\section{Associations Between Greenhouse Gas Flux and Soil Properties}

Thorough documentation of soil-atmosphere greenhouse gas flux as affected by grazing management, year, and season has been presented elsewhere (Liebig et al. 2010a, 2013; see 
Table 3. Extended.

\begin{tabular}{|c|c|c|c|c|c|}
\hline $\begin{array}{l}\text { Soil bulk density } \\
\quad\left(\mathrm{Mg} \cdot \mathrm{m}^{-3}\right)\end{array}$ & $\begin{array}{l}\text { Electrical conductivity } \\
\left(\mathrm{dS} \cdot \mathrm{m}^{-1}\right)\end{array}$ & $\begin{array}{c}\text { Soil pH } \\
\left(-\log \left[\mathrm{H}^{+}\right]\right)\end{array}$ & $\begin{array}{l}\text { Soil } \mathrm{NO}_{3}-\mathrm{N} \\
\left(\mathrm{kg} \mathrm{N} \cdot \mathrm{ha}^{-1}\right)\end{array}$ & $\begin{array}{l}\text { Soil } \mathrm{NH}_{4}-\mathrm{N} \\
\left(\mathrm{kg} \mathrm{N} \cdot \mathrm{ha}^{-1}\right)\end{array}$ & $\begin{array}{c}\text { Microbial biomass } \mathrm{C} \\
\left(\mathrm{kg} \mathrm{C} \cdot \mathrm{ha}^{-1}\right)\end{array}$ \\
\hline $1.15 \pm 0.01$ SEM & $0.28 \pm 0.02$ SEM & $5.76 \pm 0.06$ SEM & $5.2 \pm 1.2$ SEM & $2.0 \pm 0.2$ SEM & $322 \pm 52$ SEM \\
\hline $1.17 \pm 0.01$ SEM & $0.29 \pm 0.02$ SEM & $5.87 \pm 0.09$ SEM & $3.3 \pm 0.7$ SEM & $1.2 \pm 0.2$ SEM & $553 \pm 81$ SEM \\
\hline $1.14 \pm 0.01$ SEM & $0.25 \pm 0.02$ SEM & $5.74 \pm 0.05$ SEM & $7.6 \pm 1.3$ SEM & $5.6 \pm 0.9$ SEM & $391 \pm 70$ SEM \\
\hline 0.3144 & 0.1825 & 0.3100 & 0.0540 & $<0.0001$ & 0.1029 \\
\hline $1.02 \pm 0.01$ SEM & $0.25 \pm 0.01$ SEM & $6.44 \pm 0.02$ SEM & $1.6 \pm 0.3 \mathrm{SEM}$ & $1.7 \pm 0.1$ SEM & $422 \pm 50$ SEM \\
\hline $1.00 \pm 0.02$ SEM & $0.27 \pm 0.02$ SEM & $6.57 \pm 0.03 \mathrm{SEM}$ & $0.5 \pm 0.1$ SEM & $0.9 \pm 0.1$ SEM & $524 \pm 27$ SEM \\
\hline $1.00 \pm 0.01$ SEM & $0.23 \pm 0.02$ SEM & $6.52 \pm 0.04$ SEM & $1.2 \pm 0.4$ SEM & $2.7 \pm 0.2$ SEM & $329 \pm 97$ SEM \\
\hline 0.7993 & 0.0686 & 0.0653 & 0.0049 & $<0.0001$ & 0.1615 \\
\hline $1.05 \pm 0.01$ SEM & $0.25 \pm 0.01$ SEM & $6.23 \pm 0.03$ SEM & $1.9 \pm 0.4$ SEM & $2.1 \pm 0.3$ SEM & $267 \pm 53$ SEM \\
\hline $1.04 \pm 0.02$ SEM & $0.27 \pm 0.01$ SEM & $6.40 \pm 0.07$ SEM & $1.1 \pm 0.2$ SEM & $1.2 \pm 0.2$ SEM & $367 \pm 88$ SEM \\
\hline $1.07 \pm 0.02$ SEM & $0.21 \pm 0.02$ SEM & $6.32 \pm 0.03$ SEM & $1.4 \pm 0.2$ SEM & $2.5 \pm 0.3$ SEM & $402 \pm 51$ SEM \\
\hline 0.5545 & 0.0004 & 0.0030 & 0.0251 & 0.0627 & 0.3684 \\
\hline
\end{tabular}

supplemental information for synopsis, available online at http://dx.doi.org/10.2111/REM-D-13-00145.s1). Moderate relationships between soil-atmosphere gas flux and measured soil properties were observed through stepwise regression (Table 4). Across measured gases and soil depths, total model $r^{2}$ ranged from $0.09\left(\mathrm{~N}_{2} \mathrm{O}\right.$ flux, $\left.0-5 \mathrm{~cm}\right)$ to $0.76\left(\mathrm{CO}_{2}\right.$ efflux, 5-10 cm). Partial model $r^{2}$-relating to a single gas flux/soil property association-ranged from $0.03\left(\mathrm{CO}_{2}\right.$ efflux and soil bulk density, 5-10 cm) to $0.43\left(\mathrm{~N}_{2} \mathrm{O}\right.$ flux and electrical conductivity, $5-10 \mathrm{~cm}$ ). Out of a total of 36 potential gas flux/ soil property associations, 13 were significant. Six significant associations were observed with $\mathrm{CO}_{2}$ efflux, four with $\mathrm{N}_{2} \mathrm{O}$ flux, and three with $\mathrm{CH}_{4}$ flux. Across measured gases, electrical conductivity was included most frequently in the model (four), followed by soil bulk density (three), and soil $\mathrm{pH}, \mathrm{NO}_{3}-\mathrm{N}$, and $\mathrm{NH}_{4}-\mathrm{N}$ (two each).
In addition to the stepwise analysis, notable relationships between soil properties were observed during the study $(n=216$, data not shown). Electrical conductivity was positively correlated with soil $\mathrm{NO}_{3}-\mathrm{N}(r=0.32, P \leq 0.0001)$, whereas soil $\mathrm{pH}$ was negatively correlated with both soil $\mathrm{NO}_{3}-\mathrm{N}(r=-0.69, P \leq 0.0001)$ and soil $\mathrm{NH}_{4}-\mathrm{N}(r=-0.50$, $P \leq 0.0001)$.

\section{DISCUSSION}

Treatment effects on soil properties suggested grazing management indicative of CWP with supplemental $\mathrm{N}$ will result in near-surface soil conditions that are more compact and acidic than grazed permanent pastures without supplemental $\mathrm{N}$. Furthermore, management of CWP created a paradox of nutrient availability and nutrient cycling capacity within the

Table 4. Partial $r^{2}$ values from stepwise regression analysis based on model: soil-atmosphere greenhouse gas flux $\left(\mathrm{CO}_{2}, \mathrm{CH}_{4}\right.$, or $\left.\mathrm{N}_{2} \mathrm{O}\right)=\mathrm{Soil}$ bulk density, electrical conductivity, soil $\mathrm{pH}$, soil $\mathrm{NO}_{3}-\mathrm{N}$, soil $\mathrm{NH}_{4}-\mathrm{N}$, microbial biomass $\mathrm{C}$. Values in each regression were selected using a significance criterion of $P \leq 0.1$.

\begin{tabular}{|c|c|c|c|c|c|c|}
\hline Variable/depth (cm) & Soil bulk density & Electrical conductivity & Soil pH & Soil $\mathrm{NO}_{3}-\mathrm{N}$ & Soil $\mathrm{NH}_{4}-\mathrm{N}$ & Microbial biomass $\mathrm{C}$ \\
\hline \multicolumn{7}{|l|}{$\mathrm{CO}_{2}$ efflux } \\
\hline $0-5$ & & 0.23 & 0.07 & 0.16 & & \\
\hline $5-10$ & 0.03 & 0.36 & & 0.37 & & \\
\hline \multicolumn{7}{|l|}{$\mathrm{CH}_{4}$ flux } \\
\hline $0-5$ & 0.33 & & & & 0.10 & \\
\hline $5-10$ & & 0.26 & & & & \\
\hline \multicolumn{7}{|l|}{$\mathrm{N}_{2} \mathrm{O}$ flux } \\
\hline $0-5$ & 0.09 & & & & & \\
\hline $5-10$ & & 0.43 & 0.06 & & 0.06 & \\
\hline
\end{tabular}

${ }^{1} \mathrm{CO}_{2}$ indicates carbon dioxide; $\mathrm{CH}_{4}$, methane; $\mathrm{N}_{2} \mathrm{O}$, nitrous oxide; $\mathrm{NO}_{3}-\mathrm{N}$, nitrate nitrogen; $\mathrm{NH}_{4}-\mathrm{N}$, ammonium nitrogen; and $\mathrm{C}$, carbon. 
0-5 cm depth, with levels of available $\mathrm{N}$ highest and microbial biomass $\mathrm{C}$ lowest in CWP among the three evaluated pastures. Based on the amplitude and frequency of soil property differences among seasons and years, our hypothesis of increased variation with $\mathrm{N}$ application and/or increased stocking rate $(\mathrm{CWP} \geq \mathrm{HGP}>\mathrm{MGP})$ was not rejected.

Higher stocking rate, resulting in increased frequency of cattle trampling, likely contributed to greater near-surface soil bulk density in CWP compared to the permanent pastures, which in addition to being grazed at a lower stocking rate, were primarily composed of sod-forming grasses (Wienhold et al. 2001). Previous evaluations of ungrazed crested wheatgrass and native vegetation found no difference in soil bulk density at 0-15 cm (Broersma et al. 2000), but greater soil penetration resistance in the latter at $7.5-\mathrm{cm}$ and $9-\mathrm{cm}$ depths when grazed (Krzic et al. 2000). Annual fall application of $\mathrm{N}$ fertilizer, coupled with acid-forming $\mathrm{N}$ cycling processes, resulted in greater extractable $\mathrm{NO}_{3}-\mathrm{N}$ and $\mathrm{NH}_{4}-\mathrm{N}$ and lower soil $\mathrm{pH}$ in CWP compared to HGP and MGP at 0-10 cm (Berg 1986). Between permanent pastures, soil pH in HGP was greater than MGP at both depths, the result of which was likely caused by a plant community-induced shift that contributed to higher concentrations of basic cations (e.g., exchangeable $\mathrm{Ca}^{+2}$ and $\mathrm{Mg}^{+2}$ ) in the former (Liebig et al. 2006). Soil pH outcomes contributed to lower microbial biomass $\mathrm{C}$ at $0-5 \mathrm{~cm}$ in CWP compared to the permanent pastures; a finding consistent in other ecosystems where soil acidification decreased microbial biomass and narrowed the spectrum of adaptable microbial species (Kowalenko et al. 1978; Aciego Pietri et al. 2008; Rousk et al. 2010).

Temperature-dependent processes affecting nutrient mineralization and plant growth contributed to seasonal dynamics in soil chemical properties. Nitrification over the growing season likely led to a drawdown of soil $\mathrm{NH}_{4}-\mathrm{N}$ in the grazing treatments with a corresponding peak in soil $\mathrm{NO}_{3}-\mathrm{N}$ during the summer months. Increased soil $\mathrm{NO}_{3}-\mathrm{N}$ during summer is not uncommon under grazing land, and may have been facilitated by wet/dry cycles common April through June, which would serve to increase mineralization and substrate availability (Chen et al. 2001). Inconsistent trends between electrical conductivity and soil $\mathrm{NO}_{3}-\mathrm{N}$ and $\mathrm{NH}_{4}-\mathrm{N}$ across seasons suggest other ions in solution were responsible for seasonal dynamics in electrical conductivity. Interestingly, the lowest values of soil $\mathrm{pH}$ across seasons matched the highest values of soil $\mathrm{NO}_{3}-\mathrm{N}$ in each grazing treatment, possibly reflecting increased hydrogen ion generation from nitrified $\mathrm{NH}_{4}-\mathrm{N}$ (Berg 1986; Mapfumo et al. 2000).

Nitrogen inputs and stocking rate appeared to affect annual variation in soil properties. Decreased soil bulk density between years 1 and 2 in CWP and HGP did not correspond to increases in root biomass, though aboveground biomass was on average over two-fold greater across grazing treatments in year 1 compared to year 2 (Liebig et al. 2013). It is possible that increased canopy cover from greater aboveground biomass in year 2 contributed to lower near-surface soil bulk density in grazing treatments subjected to higher stocking rates (Tate et al. 2004). Levels of $\mathrm{N}$ inputs among grazing treatments likely affected soil $\mathrm{pH}$ trends over the 3-yr evaluation period, with increased soil acidification prevalent in the surface depth of CWP. The approximate $0.2 \mathrm{pH}$ unit decrease in CWP over $3 \mathrm{yr}$ was slightly greater than $\mathrm{pH}$ rate declines observed in related $\mathrm{N}$ fertilization studies under pasture (Smika et al. 1961; Owensby et al. 1969), and may be a reflection of decreased buffer capacity at lower pH (Liebig et al. 2006). Drought-induced accumulation of soil $\mathrm{NO}_{3}-\mathrm{N}$ and $\mathrm{NH}_{4}-\mathrm{N}$ during year 3 occurred under CWP and HGP but not MGP. Lower stocking rate, coupled with the absence of $\mathrm{N}$ fertilization, served to buffer large fluctuations in available N in MGP under limited precipitation. Such an attribute would be expected to limit N loss to the environment under improved (i.e., nondrought) conditions (Wedin 1999).

Stepwise regression served to identify the relative sensitivity of $\mathrm{CO}_{2}, \mathrm{CH}_{4}$, and $\mathrm{N}_{2} \mathrm{O}$ fluxes to near-surface soil properties, while concurrently highlighting the potential role of electrical conductivity as a screening indicator for greenhouse gas "hot spots" in grazing land (and not plant-available $\mathrm{N}$, as hypothesized). Among measured greenhouse gas fluxes, $\mathrm{CO}_{2}$ efflux-an integrative measure of plant and microbial respiration-was most frequently associated with soil properties. In contrast, significant associations between soil properties and $\mathrm{CH}_{4}$ and $\mathrm{N}_{2} \mathrm{O}$ fluxes-processes mediated by highly specialized microorganisms (Paul and Clark 1996)—were less common. Although greenhouse gas fluxes are often related to soil moisture and/or temperature dynamics, results from this study were consistent with other investigations in which basic soil physical and chemical properties provided insight on the role of soil condition to affect soil-atmosphere gas fluxes (Allaire et al. 2012). Increased soil porosity has been associated with higher $\mathrm{CO}_{2}$ efflux (de Figueiredo Brito et al. 2009), suggesting improved gas flux transfer to the atmosphere with lower soil bulk density. Among chemical properties, electrical conductivity has been negatively associated with $\mathrm{CO}_{2}$ efflux (Allaire et al. 2012), whereas soil $\mathrm{pH}$ and soil organic matter were found to be primary factors for explaining variation in $\mathrm{N}_{2} \mathrm{O}$ flux for an alluvial soil in northern Japan (Yanai et al. 2003). Though far from a mechanistic understanding of soil-gas flux relationships, these findings provide insight for efforts to use site-specific soil management as a means to mitigate greenhouse gas fluxes from agroecosystems.

The number and relative strength of associations between electrical conductivity and greenhouse gas fluxes suggest the former may serve as a useful screening property for identifying areas in grazing land with elevated greenhouse gas flux. As a relative measure of the total quantity of ions in soil solution, electrical conductivity has been proposed as an integrative assessment for monitoring coupling/decoupling of nutrient cycles (Patriquin et al. 1993). Positive associations between electrical conductivity and extractable $\mathrm{N}$ in nonsaline and noncalcareous soils are well established (Smith and Doran 1996; Eigenberg et al. 2006), and highlight the potential role of electrical conductivity as surrogate for available N, which, in turn, affects key metabolic processes contributing to greenhouse gas flux (Robertson and Vitousek 2009). Given the relative ease of in-situ assessments of electrical conductivity (Johnson et al. 2001; Arnold et al. 2005), extension of nearsurface electrical conductivity findings toward relative categorizations of greenhouse gas "hot spots" (e.g., field areas associated with former watering sites or bale grazing) may serve to facilitate spatially strategic management practices aimed at reducing $\mathrm{N}$ loss from grazing lands. 


\section{IMPLICATIONS}

Insight into the resilience of rangelands to buffer changes induced by external stressors requires intra- and interannual measurements of key ecosystem components, including soil. Our data show near-surface soil properties exhibited strong responses to not just grazing management, but also year and season. Grazing management indicative of a CWP fertilized annually with $\mathrm{N}$ resulted in near-surface soil conditions that were more compact and acidic than grazed permanent pastures without supplemental N. Such conditions under crested wheatgrass contributed wide fluctuations in extractable $\mathrm{N}$ over time (particularly during a drought year), as well as significantly lower microbial biomass. Results suggested the potential role of electrical conductivity to serve as a screening indicator for greenhouse gas "hot spots" in grazing land.

\section{ACKNOWLEDGMENTS}

The authors gratefully acknowledge David Brandt, Patrick Kilzer, Angela Renner, Gail Sage, and Becky Wald for their assistance with sample collection and laboratory analyses. We also thank Kurt Reinhart, Shan Lin, and Jeff Printz for their helpful comments to improve an earlier draft of this manuscript.

\section{LITERATURE CITED}

Aciego Pietri, J. C., And P. C. Brookes. 2008. Relationships between soil pH and microbial properties in a UK arable soil. Soil Biology and Biochemistry 40:18561861.

Allaire, S. E., S. F. Lange, J. A. Lafond, B. Pelletier, A. N. Cambouris, and P. Dutilleul. 2011. Multiscale spatial variability of $\mathrm{CO}_{2}$ emissions and correlations with physico-chemical soil properties. Geoderma 170:251-260.

Arnold, S. L. , J. W. Doran, J. Schepers, B. Wienhold, D. Ginting, B. Amos, and S. Gomes. 2005. Portable probes to measure electrical conductivity and soil quality in the field. Communications in Soil Science and Plant Analysis 36(15-16):22712287.

Baneruee, M. R., D. L. Burton, W. P. McCaughey, and C. A. Grant. 2000. Influence of pasture management on soil biological activity. Journal of Range Management 53:127-133.

BERG, W. A. 1986. Effect of 20 years of low $\mathrm{N}$ rate pasture fertilization on soil acidity. Journal of Range Management 39:122-124.

Blake, G. R., and K. H. Hartge. 1986. Bulk density. In: A. Klute [ed.]. Methods of soil analysis. Part 1-physical and mineralogical methods. 2nd ed. Soil Science Society of America Book Series No. 5. Madison, WI, USA: Soil Science Society of America and American Society of Agronomy. p. 363-382.

Broersma, K., M. Krzic, D. J. Thompson, and A. A. Bomke. 2000. Soil and vegetation of ungrazed crested wheatgrass and native rangelands. Canadian Journal of Soil Science 80:411-417.

Chen, Q., D. U. Hooper, and S. Lin. 2011. Shift in species composition constrain restoration of overgrazed grassland using nitrogen fertilization in Inner Mongolian steppe, China. PLoS ONE 6(3):e16909.

Chen, W., W. P. McCaughey, C. A. Grant, and L. D. Balley. 2001. Pasture type and fertilization effects on soil chemical properties and nutrient distribution. Canadian Journal of Soil Science 81:395-404.

Daly, G. C., P. A. Matson, and P. M. Vitousek. 1997. Ecosystem services supplied by soils. In: G. C. Daly [ED.]. Nature's services: societal dependence on natural ecosystems. Washington, DC, USA: Island Press. p. 113-132.

Darnhofer, I., J. Falrweather, And H. Moller. 2010. Assessing a farm's sustainability: insights from resilience thinking. International Journal of Sustainable Agriculture 8:186-198. de Figuelredo Brito, L., J. M. Junior, G. T. Pereira, Z. M. Souza, and N. La Scala, Jr. 2009. Soil $\mathrm{CO}_{2}$ emission of sugarcane as affected by topography. Scientia Agricola 66:77-83.

Dougill, A. J, A. L. Heathwaite, and D. S. G. Thomas. 1998. Soil water movement and nutrient cycling in semi-arid rangeland: implications for patterns of vegetation change and system resilience. Hydrological Processes 12:443-459.

Eigenberg, R. A., J. A. Nienaber, B. L. Woodbury, and R. B. Ferguson. 2006. Soil conductivity as a measure of soil and crop status-a four-year summary. Soil Science Society of America Journal 70:1600-1611.

Follett, R. F., AND D. A. ReED. 2010. Soil carbon sequestration in grazing lands: societal benefits and policy recommendations. Rangeland Ecology \& Management 63:4-15.

Frank, A. B., M. A. Liebig, and D. L. Tanaka. 2006. Management effects on soil $\mathrm{CO}_{2}$ efflux in northern semiarid grassland and cropland. Soil Tillage Research 89:7885.

Franzluebbers, A. J., R. L. Haney, F. M. Hons, and D. A. Zuberer. 1999. Assessing biological soil quality with chloroform fumigation-incubation: why subtract a control? Canadian Journal of Soil Science 79:521-528.

Gomez, K. A., AND A. A. Gomez. 1984. Statistical procedures for agricultural research. 2nd ed. New York, NY, USA: John Wiley and Sons. 704 p.

Hutchinson, G. L., And A. R. Mosier. 1981. Improved soil cover method for field measurements of nitrous oxide fluxes. Soil Science Society of America Journal 45:311-316.

Ingram, L. J., P. D. Stahl, G. E. Schuman, J. S. Buyer, G. F. Vance, G. K. Ganjegunte, J. M. WelKer, AND J. D. Derner. 2008. Grazing impacts on soil carbon and microbial communities in a mixed-grass ecosystem. Soil Science Society of America Journal 72:939-948.

Islam, K. R., AND R. R. Well. 1998. Microwave irradiation of soil for routine measurement of microbial biomass carbon. Biology and Fertility of Soils 27:408416.

Johnson, C. K., J. W. Doran, H. R. Duke, B. J. Wienhold, K. M. Eskridge, and J. F. Shanahan. 2001. Field-scale electrical conductivity mapping for delineating soil condition. Soil Science Society of America Journal 65:1829-1837.

Kowalenko, C. G., K. C. Ivarson, and D. R. Cameron. 1978. Effect of moisture content, temperature and nitrogen fertilization on carbon dioxide evolution from field soils. Soil Biology and Biochemistry 10:417-423.

Krzlc, M., K. Broersma, D. J. Thompson, and A. A. Bomke. 2000. Soil properties and species diversity of grazed crested wheatgrass and native rangelands. Journal of Range Management 53:353-358.

Liebig, M. A., J. R. Gross, S. L. Kronberg, J. D. Hanson, A. B. Frank, and R. L. Phillips. 2006. Soil response to long-term grazing in the northern Great Plains of North America. Agriculture Ecosystems and Environment 115:270-276.

Liebig, M. A., J. R. Gross, S. L. Kronberg, R. L. Phillips, and J. D. Hanson. 2010a. Grazing management contributions to net global warming potential: a long-term evaluation in the northern Great Plains. Journal of Environmental Quality 39(3):799-809.

Liebig, M. A., S. L. Kronberg, J. R. Hendrickson, X. Dong, and J. R. Gross. 2013. Soil $\mathrm{CO}_{2}$ efflux from long-term grazing management systems in a semiarid region. Agriculture Ecosystems and Environment 164:137-144.

LieBiG, M. A., G. E. Varvel, and C. W. Honeycutt. 2010b. Sampling protocols. Chapter 1. Guidelines for site description and soil sampling, processing, analysis, and archiving. In: R. F. Follett [ED.]. GRACEnet sampling protocols. p. 1-1 to 1-5. Available at: http://www.ars.usda.gov/research/GRACEnet. Accessed 2 March 2014.

Littell, R. C., G. A. Milliken, W. W. Stroup, and R. D. Wolfinger. 1996. SAS system for mixed models. Cary, NC, USA: SAS Institute, Inc. 656 p.

Mapfumo, E., D. S. Chanasyk, V. S. Baron, and M. A. Naeth. 2000. Grazing impacts on selected soil parameters under short-term forage sequences. Journal of Range Management 53:466-470.

Mulvaney, R. L. 1996. Nitrogen—inorganic forms. In: D. L. Sparks [ed.]. Methods of soil analysis. Part 3. Chemical methods. Soil Science Society of America Book Series No. 5. Madison, WI, USA: Soil Science Society of America and American Society of Agronomy. p. 1123-1184.

[NDAWN] North Dakota Agricultural Weather Network. 2014. NDAWN station locations. Available at: http://ndawn.ndsu.nodak.edu/index.html. Accessed 28 February 2014. 
National Drought Mitigation Center. 2014. US drought monitor. Available at: http:// droughtmonitor.unl.edu/. Accessed 28 February 2014.

Owensby, C. E., K. L. Anderson, And D. A. Whitney. 1969. Some chemical properties of a silt loam soil after 20 years' nitrogen and phosphorus fertilization of smooth bromegrass (Bromus inermis Leyss.). Soil Science 108:24-29.

Patriquin, D. G., H. Blaikie, M. J. Patriquin, and C. Yang. 1993. On-farm measurements of $\mathrm{pH}$, electrical conductivity and nitrate in soil extracts for monitoring coupling and decoupling of nutrient cycles. Biological Agriculture and Horticulture 9:231272.

Paul, E. A., and F. E. Clark. 1996. Soil microbiology and biochemistry. 2nd ed. San Diego, CA, USA: Academic Press, Inc. 340 p.

Phillips, R. L., D. L. Tanaka, D. W. Archer, and J. D. Hanson. 2009. Fertilizer application timing influences greenhouse gas fluxes over a growing season. Journal of Environmental Quality 38:1-11.

Reeves, J. L., J. D. Derner, M. A. Sanderson, M. K. Petersen, L. T. Vermeire, J. R. HendRICKSON, AND S. L. KronBerg. 2013. Temperature and precipitation affect steer weight gains differentially by stocking rate in northern mixed-grass prairie. Rangeland Ecology \& Management 66:438-444.

Robertson, G. P., AND P. M. Vitousek. 2009. Nitrogen in agriculture: balancing the cost of an essential resource. Annual Review of Environment and Resources 34:97125

Rousk, J., E. BÅÅth, P. C. Brookes, C. L. Lauber, C. Lozupone, J. G. Caporaso, R. Knight, AND N. FIERER. 2010. Soil bacterial and fungal communities across a pH gradient in an arable soil. ISME Journal 10:1340-1351.

SARVIS, J. T. 1923. Effects of different systems and intensities of grazing upon the native vegetation at the Northern Great Plains field station. Washington DC, USA US Government Printing Office. USDA, Dept. Bull. 1170. 45 p.

SAS Institute. 1990. SAS/STAT user's guide. Version 6.0. Volume 2. 4th ed. Cary, NC, USA: SAS Institute, Inc. 1848 p.

Smika, D. E., H. J. HaAs, G. A. Rogler, and R. J. Lorenz. 1961. Chemical properties and moisture extraction in rangeland soils as influenced by nitrogen fertilization. Journal of Range Management 14:213-216.

Smith, J. L., AND J. W. Doran. 1996. Measurement and use of pH and electrical conductivity for soil quality analysis. In: J. W. Doran and A. J. Jones [EDS.]. Methods for assessing soil quality. SSSA Spec. Publ. 49. Madison, WI, USA: American Society of Agronomy, Crop Science Society of America, and Soil Science Society of America. p. 169-185.

Steffens, M., A. Kölbl, K. U. TotSche, And I. Kölbl-Knabner. 2008. Grazing effects on soil chemical and physical properties in a semiarid steppe of Inner Mongolia (P.R. China). Geoderma 143:63-72.
Tate, K. W., D. M. Dudley, N. K. McDougland, and M. R. George. 2004. Effect of canopy and grazing on soil bulk density. Journal of Range Management 57:411-417.

Teague, W. R., S. L. Dowhower, S. A. Baker, N. Halle, P. B. Delaune, and D. M. Conover. 2011. Grazing management impacts on vegetation, soil biota and soil chemical, physical and hydrological properties in tall grass prairie. Agriculture Ecosystems and Environment 141:310-322.

ThuRow, T. L. 1991. Hydrology and erosion. In: R. K. Heitschmidt and J. W. Stuth [EDS.]. Grazing management: an ecological perspective. Portland, OR, USA: Timber Press. p. 141-159.

USDA. 1993. Soil survey manual. USDA Soil Survey Division Staff. US Department of Agriculture Handbook No. 18. Washington, DC, USA: US Government Printing Office.

USDA. 2013. Natural Resources Conservation Service, United States Department of Agriculture. Web soil survey. Available at: http://websoilsurvey.nrcs.usda.gov/. Accessed 23 September 2013.

Watson, M. E., AND J. R. Brown. 1998. pH and lime requirement. In: J. R. Brown [ed.]. Recommended chemical soil test procedures for the North Central Region. North Central Region Publication 221 (revised). Columbia, MO, USA: Missouri Agriculture Experiment Station. Bulletin SB1001. p. 13-16.

WEDIN, D. A. 1999. Nitrogen availability, plant-soil feedbacks and grassland stability. In: D. Eldridge and D. Freudenberger [EDS.]. People and rangelands: building the future. Proceedings of the VI International Rangeland Congress. Volume 1; 19-23 July 1999; Townsville, Queensland, Australia. Townsville, Queensland, Australia: International Rangeland Congress. p. 193-197.

Westoby, M., B. Walker, and I. Noy-MelR. 1989. Opportunistic management for rangelands not at equilibrium. Journal of Range Management 42:266-274.

Whalen, J. K., W. D. Willms, and J. F. Dormaar. 2003. Soil carbon, nitrogen and phosphorus in modified rangeland communities. Journal of Range Management 56:665-672.

Whitney, D. A. 1998. Soil salinity. In: J. R. Brown [ED.]. Recommended chemical soil test procedures for the North Central Region. North Central Region Publication 221 (revised). Columbia, M0, USA: Missouri Agriculture Experiment Station Bulletin. SB1001. p. 59-60.

Wienhold, B. J., J. R. Hendrickson, and J. F. Karn. 2001. Pasture management influences on soil properties in the northern Great Plains. Journal of Soil and Water Conservation 56(1):27-31.

Yanal, J., T. Samamoto, T. Oe, K. Kusa, K. Yamakawa, K. Sakamoto, T. Naganawa, K. InUBuSH, R. Hatano, and T. KosakI. 2003. Spatial variability of nitrous oxide emissions and their soil-related determining factors in an agricultural field. Journal of Environmental Quality 32:1965-1977. 